\title{
Secession and Intervention in the Former Soviet Space: The Crimean Incident and Russian Interference in Its 'Near Abroad'
}

\author{
Gary Wilson ${ }^{1}$
}

Published online: 27 September 2016

(C) The Author(s) 2016. This article is published with open access at Springerlink.com

\begin{abstract}
Following Russian intervention and a referendum held on 16th March 2014, the Ukrainian republic of Crimea became incorporated within Russia. The Crimean episode marked just the latest in a series of situations arising in former Soviet states in which secessionist movements within disaffected territorial units were able to advance their causes aided by Russian external intervention. These situations raise significant international legal issues pertaining to secession by component parts of existing states, underpinned by external intervention. The unwillingness of the international community to recognise Russia's incorporation of Crimea, similar to its earlier rejection of the purported secession of South Ossetia and Abkhazia from Georgia, reinforces the widely held view that non-consensual secession must be grounded in exceptional circumstances which were found to be lacking in all of these situations. It also reaffirms the principle that territorial changes brought about by external intervention will not be recognised. However, while legal assessments of these incidents may appear prima facie straightforward, they cannot be entirely divorced from the wider political phenomenon of ethnic conflict in former Soviet states and tensions existing in those states between factions seeking to further European integration and those prioritising strengthening relations with Russia. The international legal reasoning employed by the key protagonists must be understood with reference to this wider context.
\end{abstract}

Keywords Crimea $\cdot$ Secession · Intervention · Annexation · Soviet Space

Gary Wilson

G.Wilson@ljmu.ac.uk

1 Liverpool John Moores University, Liverpool, UK 


\section{Introduction}

On 16th March 2014, following tensions culminating in Russian intervention, a referendum was held within the Ukrainian republic of Crimea in which an overwhelming majority of those taking part purportedly voted in favour of Crimea's secession from Ukraine and integration within Russia. Two days later, the Kremlin proclaimed that Crimea was now part of Russia. By this point, Ukrainian authorities had effectively ceased to exercise any control over the territory, Russian military reinforcements in Crimea following its purported incorporation within the Russian Federation having ensured the departure of the remaining Ukrainian military contingents. These developments were roundly condemned by both Ukrainian authorities and large sections of the international community who regard Crimea's purported secession as little more than a case of unlawful annexation by Russia. By contrast, Russia - and evidently a clear majority of the Crimean populationconsiders union with Russia a legitimate expression of the will of the inhabitants of Crimea, many of whom are ethnic Russians and enjoy a strong historic connection with Russia.

Since Crimea's incorporation within Russia, other pro-Russian separatist movements have gained strength in the eastern regions of Donetsk and Luhansk, seizing control in those areas and holding so-called referenda in which those administering them claim overwhelming majorities in favour of independence from Ukraine (with some overtures towards possible ultimate union with Russia). The situations in these regions remain unresolved as they continue to be beset by conflict between Ukrainian military forces and Russian-backed separatist groups.

Russia's intervention in Crimea and its purported secession from Ukraine cannot be considered in isolation, but must rather be understood in the context of a series of secessionist pressures within former Soviet republics where Russia has also intervened. It has been noted that, "Crimea followed on from South Ossetia and Abkhazia as the third in a trio of "similar cases'."1 There are certainly some striking comparisons to be drawn with South Ossetia and Abkhazia, ${ }^{2}$ regions within Georgia which, supported by Russian intervention, have proclaimed their independence and currently operate as de facto states notwithstanding the almost universal refusal of the international community to recognise them. Reference to South Ossetia and Abkhazia will be relevant throughout the substantive treatment of issues concerning Crimea.

The international legal issues raised by events in Crimea, as well as South Ossetia and Abkhazia, are far from insignificant. This paper seeks to explore the issue of Crimea's purported secession from Ukraine during 2014 against a backdrop of external intervention by Russia. We consider this event primarily with reference to the relevant international legal norms, but also within its geopolitical context. We begin by providing some historical context to events in Crimea; in light of the similarities between the cases, by way of background to understanding Russian

\footnotetext{
1 Navari (2014: 1313).

2 Navari (2014: 1314) notes that all three secessionist entities "claimed varying degrees of political suppression and subjection to the threat and use of violence".
} 
claims made in respect of Crimea, we briefly outline the course of events in South Ossetia and Abkhazia leading to their de facto independence from Georgia. The development of Crimea's status through the Soviet era to the present day is then detailed. Attention is then given to the concept of secession in international law and the relevant framework applicable to its exercise, before more specifically to the question of whether Crimea could stake an entitlement under international law to secede from Ukraine. We also consider Russia's involvement in events, and the extent to which this is unlawful and effectively give rise to the annexation of Crimea. Finally, the geopolitical factors relevant to an understanding of the Crimean episode, and the manner in which these have informed the legal arguments employed by the key actors involved, are considered, as well as some of the inconsistencies in legal discourse which they highlight.

\section{Historical Background}

\section{A Note on South Ossetia and Abkhazia}

As has already been noted, the Crimean episode bears some resemblance to earlier developments within the Georgian provinces of South Ossetia and Abkhazia, and reference to those developments will be helpful in providing some context to the more recent events in Crimea. South Ossetia is a semi-autonomous region within Georgia, the population of which is predominantly ethnically Ossetian, a group divided between South Ossetia in Georgia and North Ossetia in Russia. Ethnic Georgians comprise only a minority group within South Ossetia, albeit a sizeable one. ${ }^{3}$ The Ossetian people are of Iranian origin and enjoy a distinctive culture, language, and history of self-rule. ${ }^{4}$ South Ossetia had been under Russian rule during the nineteenth century, ${ }^{5}$ and although always part of Georgia during the Soviet era, the population of South Ossetia have a long history of good relations with Russia, ${ }^{6}$ it being home to the larger share of the ethnic Ossetian population within the region. In the post-Cold War era tensions between South Ossetia and Georgia have always been present. Surveys have revealed significant levels of mutual distrust between Georgians and South Ossetians, ${ }^{7}$ and following conflict between South Ossetian and Georgian forces in the early 1990s, a Russian led peacekeeping presence was deployed to South Ossetia. ${ }^{8}$ On a number of occasions South Ossetia sought to advance the cause of independence. Having declared its sovereignty in 1990, in a 1992 referendum its population backed independence and

\footnotetext{
3 Approximately 20-30\% at the time of the outbreak of the August 2008 war. See Toomey (2009: 445-449).

4 See the BBC profile for South Ossetia, www.bbc.co.uk/news/world-europe-18269210. See also Higgins and O'Reilly (2009: 580).

5 See NuBberger (2009: 351).

6 See Toomey (2009: 445-449).

7 Higgins and O'Reilly (2009: 568-570).

8 See Petro (2008: 1528-1533).
} 
from that point South Ossetia effectively functioned de facto independently of Georgian authority, reiterating its independence again on further occasions. ${ }^{9}$

Tensions heightened following Georgian President Saakashvili's push to reassert Georgian sovereignty over South Ossetia, ${ }^{10}$ leading to a full-blown war between Georgian and Russian/South Ossetian forces during August 2008. ${ }^{11}$ Both sides traded blame for the violence, ${ }^{12}$ which ended after 5 days. South Ossetia's declaration of independence at this time was recognised by Russia, ${ }^{13}$ although heavily condemned by the international community at large which still regards it as de jure part of Georgia. ${ }^{14}$

Like South Ossetia, Abkhazia is a semi-autonomous region within Georgia which has experienced tensions with its parent state. ${ }^{15}$ For a long time Abkhazia was an independent territory, before becoming subsumed within first the Osman empire, then from 1810 onwards the Russian empire. Within the Soviet Union, it was initially a separate republic until its integration within Georgia by decree of Stalin in 1931. The Abkhaz people have little in common with either Russia or Georgia, enjoying a distinct culture and language, and being adherents of Islam. ${ }^{16}$ As the USSR began to dissolve, tensions increased and Abkhazia asserted its independence, conflict breaking out with Georgia in 1992. A Russian brokered agreement restored peace in 1994, ${ }^{17}$ although like South Ossetia, Abkhazia has effectively operated as a de facto independent state since. Its status was strengthened in 2008 when conflict in South Ossetia spread to Abkhazia, and Russia recognised Abkhazian independence at the same time that it extended recognition to South Ossetia.

\section{Crimea}

The area comprising present day Crimea has been controlled by various groups throughout its history. ${ }^{18}$ For centuries predominantly populated by Crimean Tatars, ${ }^{19}$ it came under full Russian control in the late eighteenth century. ${ }^{20}$ Crimea remained part of Russia into the Soviet era until it was transferred to the Ukraine in

\footnotetext{
${ }^{9}$ For example, in a 2006 referendum, $95 \%$ purportedly backed independence. See, eg., 'South Ossetians vote for independence', The Guardian, 13 November 2006, www.theguardian.com/world/2006/nov/13/ russia.georgia.

10 See Chatham (2011: 77-78).

11 For brief details, see Toomey (2009: 450-452).

12 See Musselman (2010: 322-324) and NuBberger (2009: 345-346).

13 See Higgins and O'Reilly (2009: 571-573).

14 See Musselman (2010: 325-329).

15 See the BBC profile for Abkhazia, www.bbc.co.uk/news/world-europe-18175030.

16 See Davies (1997: 816).

17 See NuBberger (2009: 361-362).

18 Wydra (2004: 112).

19 See Magosi (1996: 172-178).

20 See Wydra (2004: 112).
} 
1954. ${ }^{21}$ While the population remained largely Russian, the 1954 transition was mainly symbolic given that both Russia and Ukraine belonged to the same sovereign state, the USSR. While Ukraine remained relatively peaceful as early post-Cold War secessionist conflicts flared up in other ex-Soviet states, including Georgia, ${ }^{22}$ Crimea was nonetheless identified as one potential source of tension at that time, one observer noting that, "The Crimea has been specifically referred to as, 'one of the most sensitive regions in South-Eastern Europe", adding that "there is fear that it will turn into yet another 'hot spot' in the growing list of ethnic conflicts throughout Eastern Europe and the former Soviet Union., ${ }^{23}$

A key factor in the secessionist threat within Crimea has undoubtedly been the existence of a sizeable ethnic Russian population. ${ }^{24}$ In the early years of Ukrainian independence post-Cold War, concessions were made to Crimea in respect of political, cultural and economic autonomy, ${ }^{25}$ although relative stability prevailed until the events of early 2014. These events have to be understood against the backdrop of East-West tensions in Ukraine. Since the dissolution of the USSR, the country has experienced tensions between its broadly pro-European western regions which demonstrate greater support for Ukraine's attempt to attain membership of the European Union and move the country towards integration within European political structures, such as NATO, and its broadly pro-Russian eastern regions which favour the retention of close relations with Russia. ${ }^{26}$

The so-called 'Euromaidan' movement began in November 2013 with protests against the government of President Viktor Yanyukovych, after he reneged on plans to sign a comprehensive trade agreement with the European Union. ${ }^{27}$ Beginning as peaceful protests, the uprisings in the capital, Kiev, intensified in February 2014 and culminated in Parliament's impeachment of President Yanyukovych, his departure from the country, and the installation of an interim government pending new elections. ${ }^{28}$ In late February, in response to these developments, seen as designed to reassert efforts to strengthen Ukraine's relations with the EU, pro-Russian armed groups occupied and took control of Crimea. On 6th March Crimea's Parliament approved the holding of a referendum which would give citizens the option of union

\footnotetext{
${ }^{21}$ See Magosi (1996: 653).

${ }^{22}$ On some of these post-Soviet secessionist conflicts, see, eg., Gaweda and Siddi (2012); Sterio (2013: 130-160) (on Chechnya, South Ossetia, and Abkhazia).

${ }^{23}$ Chase (1996: 220).

${ }^{24}$ According to the 2001 Ukrainian census, ethnic Russians accounted for $58 \%$ of the population of Crimea, http://2001.ukrcensus.gov.ua/eng/results/general/nationality/. See also Bugajski (2000: 173-175).

${ }^{25}$ See Chase (1996: 223) and Wydra (2004: 121-129). See also Sasse (2002).

${ }^{26}$ See, eg., White et al. (2010). On ethnic and national identity more generally within post-Soviet Ukraine, see Liber (1998) and Nemyria (1999).

27 'Ukraine rally over EU agreement delay', BBC News Online, 25 November 2013, www.bbc.co.uk/ news/world-europe-25083801.

${ }^{28}$ See 'Ukrainian MPs vote to oust President Yanyukovych', BBC News Online, 24 February 2014, www.bbc.co.uk/news/world-europe-26304842. On the sequence of events leading up to Crimea's incorporation within Russia, see Smith and Harari (2014: 1). In new presidential elections held on 25 May 2014, Petro Poroshenko was elected as Ukraine's President.
} 
with Russia or enhanced autonomy. ${ }^{29}$ In that referendum, a reported $96 \%$ backed union with Russia, ${ }^{30}$ and 2 days later the Kremlin proclaimed Crimea part of Russia, President Putin placing much emphasis upon their historic links. ${ }^{31}$ The Kiev government, the EU, US and other major international actors regarded the action as unlawful, ${ }^{32}$ and Russia was suspended from the G8. ${ }^{33}$ UN Security Council condemnation of the action was only prevented by Russia's exercise of its power of veto, ${ }^{34}$ while the UN General Assembly (by a vote of 100 to 11 with 58 abstentions) called upon states not to recognize any change in Crimea's status. ${ }^{35}$ Factually, the incorporation of Crimea within Russia is a fait accompli, although it also sparked off a wave of secessionist pressures within Eastern Ukraine as large swathes of areas with large ethnic Russian populations, Donetsk and Luhansk, fell under the control of armed separatist groups sympathetic to Russia. ${ }^{36}$ These areas have subsequently held referendums on their future status, ${ }^{37}$ which remains unresolved amidst continued armed conflict.

\section{The Case for Secession or Irredentism}

Secession has been defined as "the effort of a group or section of a state to withdraw itself from the political or constitutional authority of that state." ${ }^{38}$ There has been a tendency to apply the term "secession" to those instances in which territorial entities break away from their parent state and assert their independent statehood. ${ }^{39}$ Where a territorial entity breaks away from its parent state in order to join another state-usually with which it shares ethnic, national, religious or linguistic characteristics and/or a strong historical connection-that process is generally considered an instance of irredentism. That Crimea has purported to form a union

\footnotetext{
29 See Shuster (2014: 20-25).

30 'Crimea referendum: Voters 'back Russia union', BBC News Online, 16 March 2014, www.bbc.co.uk/ news/world-europe-26606097.

31 Putin stated that, "Everything in Crimea speaks of our shared history and pride...In people's hearts and minds, Crimea has always been an inseparable part of Russia." See President Putin's Speech of 18 March 2014, available at the Kremlin website, http://eng.kremlin.ru/news/6889.

32 See, eg., 'Ukraine Crisis: Russia isolated in UN Crimea vote', BBC News Online, 15 March 2014, www.bbc.co.uk/news/world-europe-26595776.

33 See 'G8 suspends Russia for annexation of Crimea', The Telegraph, 24 March 2014, www.telegraph. co.uk/news/worldnews/europe/russia/10720297/G8-suspends-Russia-for-annexation-of-Crimea.html.

34 UN Doc. S/2014/189; UN Doc. S/PV.7138. 13 members of the Council backed the condemnatory resolution, China abstaining.

35 GA Res 68/262. See also UN Doc. GA/11493.

36 See, eg., 'Pro-Russian rebels vow to take control of infrastructure across Donetsk region', The Guardian, 14 April 2014, www.theguardian.com/world/2014/apr/14/ukraine-deadline-pro-russian-rebelspasses.

37 'Ukraine rebels hold referendums in Donetsk and Luhansk', BBC News Online, 11 May 2014, www. bbc.co.uk/news/world-europe-27360146.

38 Reference re Secession of Quebec, 2 SCR [1998] 217, at para. 83.

39 See, eg., above, where the decision goes on to define secession as a process directed towards the achievement of independent statehood on the part of the seceding entity.
} 
with Russia-unlike Abkhazia and South Ossetia, which have declared their own independent statehood-might suggest that the latter term is more suited to its treatment within the present discussion. However, it is contended that framing consideration of the Crimean episode within the parameters of discourse on secession is appropriate for two principal reasons. First, "secession" implies a breaking off from an existing territorial relationship. While it may result in independence, it can also serve as a precursor to union with another state. Indeed, some international lawyers have defined secession to encompass such an outcome. ${ }^{40}$ The legal principles which govern secession are therefore equally applicable to processes resulting in entities breaking away from one state and joining another. Second, there has been very little treatment of irredentism as a separate legal concept, ${ }^{41}$ probably owing largely to the fact that there have been so few situations in which a territorial unit seeks union with another state as opposed to outright independence.

There is a considerable degree of consensus that while international law does not explicitly prohibit secession by entities within existing states, nor does it provide any general right of secession. ${ }^{42}$ Where secession takes place with the consent of the state which is losing a part of its territory-as for example occurred when South Sudan seceded from Sudan ${ }^{43}$ - there is no great difficulty in legal terms. However, where secession is attempted against the will of the parent state it becomes necessary from a perspective of legitimacy to base this in some normative legal principles, not least in order to generate international recognition of the new arrangements. The limited international recognition of Crimea's absorption within Russia, ${ }^{44}$ and of Abkhaz and South Ossetian independence, ${ }^{45}$ suggests that the legal basis for these actions is considered lacking.

States have approached non-consensual secession cautiously. ${ }^{46}$ As Jaber has noted, "although states have consistently upheld the right to secession where it is the product of a consensual arrangement with the state, they have generally not accepted unilateral secessions that violate the territorial integrity of independent states." 47 Furthermore, it has been suggested that the "historical criteria for international recognition of claims of secession include the approval of the state from which the entity in question is seceding, the degree of repression within the larger state, historical claims of independence, the extent to which the seceding

\footnotetext{
40 See, eg., Dugard and Raic (2006: 101-102).

41 For discussion, however, in the context of Somalia, Germany and Cyprus, see Musgrave (1997: 211-229).

42 See, eg., Quebec decision, paras. 111-112.

43 For discussion, see Sheeran (2011) and Vidmar (2011-2012).

44 As of April 2014, Crimea had only been recognised as part of Russia by Afghanistan, Cuba, Nicaragua, North Korea, Syria, and Venezuela.

45 Abkhazia and South Ossetia are only recognised as independent states by Russia, Nicaragua, Venezuela, and Nauru.

46 See Halperin and Scheffer (1992: 13-16) and Crawford (2006: 388-391).

47 Jaber (2011: 934). See also Crawford (1998). Orakhelashvili (2008: 1) notes that even in the early post-Cold War era, where 21 new states rapidly came into existence, the principle that no entity may secede without the consent of its parent state retained validity.
} 
region has exhausted possibilities of a negotiated settlement of its disputes, the ability of the new state to maintain internal order and defend its borders, and the extent to which secession would be destabilizing." 48 The case of Bangladesh appears to have been the only instance in which a seceding entity has been given the legitimation of international recognition against the will of the parent state, ${ }^{49}$ although a more recent precedent might be found in respect of the large number of states to have recognized Kosovo. ${ }^{50}$

From the standpoint of international law, the starting point from which attempts to identify norms which might legitimate acts of secession might be made has usually been the principle of self-determination. ${ }^{51}$ Indeed, Russia sought to legitimise Crimea's secession from Ukraine by reference to the principle of external self-determination. ${ }^{52}$ Whereas the principle's 'internal' dimension effectively refers to the right of a state's population to determine their own political system and form of government, ${ }^{53}$ 'external' self-determination concerns the process by which a territorial unit removes itself from the sovereign authority of its parent state, whether by seceding to form a newly independent state or through union with another state. Although its philosophical and political origins can be traced much earlier, ${ }^{54}$ self-determination as a legal principle was developed through a series of UN General Assembly resolutions. ${ }^{55}$ It was at least initially conceived as a principle applicable to the decolonisation process in the post-World War Two period, ${ }^{56}$ and has been recognised by the ICJ as "one of the essential principles of contemporary international law." 57 The initial focus on decolonisation was evident in the language of General Assembly resolutions 1514 and 1541, the former being proclaimed a "declaration on the granting of independence to colonial countries and peoples" and requiring immediate steps to confer independence on trust and non-self governing territories. ${ }^{58}$ Clearly, any right to self-determination restricted to colonial peoples would be of no relevance to the populations of Crimea, Abkhazia or South Ossetia

\footnotetext{
48 Chase (1996: 232).

49 For discussion, see Buchheit (1978: 198-214), Meadwell (1999), Jaber (2011: 939-940) and Nanda (1980).

50108 UN Member States had recognised Kosovo as of 15th April 2014. For references to their various declarations of recognition, see www.kosovothanksyou.com/. The literature on Kosovo is voluminous. The more detailed treatments include Orakhelashvili (2008), Koeck et al. (2009), Weller (2009) and Summers (2011).

51 The long history of the idea of self-determination is beyond our present scope. For an overview, see Summers (2007: 83).

52 See, eg., UN Doc. S/PV.7144, at 8; UN Doc. A/68/PV.80, at 3, for Russian statements to this effect. These are detailed in Christakis (2015).

53 On the nature of internal self-determination, see Halperin and Scheffer (1992: 16-20); Summers (2013); Quebec decision, paras. 17, 33-39.

54 See Musgrave (1997: 15-31); Summers (2007).

55 See GA Res. 1514 (1960); GA Res 1541 (1960); GA Res 2625 (1970).

56 See, eg., Halperin and Scheffer (1992: 20-25), Cassese (1995: ch3) and Crawford (2006: 107-131).

57 East Timor (Portugal v Australia), ICJ Rep, 1995, 91, at para. 29. For further discussion of selfdetermination's consideration by the ICJ, see Musgrave (1997: 77-90).

58 Para. 5. Resolution 1541 defined with greater clarity the obligations imposed by resolution 1514.
} 
as they do not constitute colonial entities. However, although some scholars consider self-determination to have no application outside of the colonial context, ${ }^{59}$ there is a considerable degree of support for its relevance in a wider context. Such an understanding of its scope is largely based upon an interpretation of the so-called 'saving clause' of the Friendly Relations declaration of the UN General Assembly, which provides that:

Nothing in the foregoing paragraphs shall be construed as authorizing or encouraging any action which would dismember or impair, totally or in part, the territorial integrity or political unity of sovereign and independent States conducting themselves in compliance with the principle of equal rights and self-determination of peoples as described above and thus possessed of a government representing the whole people belonging to the territory without distinction as to race, creed, or colour. ${ }^{60}$

While beginning with a presumption against the dismemberment or impairment of the territory of an existing state, the latter part of the provision has been taken to suggest that where a state in a non-colonial setting does not afford equal protection or representation to all of its citizens, then in certain defined circumstances a sufficiently disadvantaged group within that state may have a right of 'remedial' secession. Effectively, because it has been unable to exercise a right of internal selfdetermination through adequate participation and representation within the state's political structures, the right to self-determination can only be exercised externally through an act of "divorce" from the state; secession. While there is some support for such a view, ${ }^{61}$ there is no clear consensus upon this matter, ${ }^{62}$ although it is suggested that support for 'remedial secession' has grown in recent times. ${ }^{63}$ Without clearly defined criteria, there is obviously a danger that acknowledging a right to secede opens the door to a broad range of claims from various dissatisfied minority groupings. The main areas of debate concern the form of action on the part of the parent state which will give rise to a right of secession for an oppressed group, and who constitutes a 'people' capable of exercising such a right.

While self-determination is stated within the various instruments to be a right of "peoples", there is no universal definition as to who constitutes a "people" for such purposes. Resolution 2625 itself makes reference to "race, creed, or colour" as characteristics of a people, and those attempts that have been made to define the term "peoples" for self-determination purposes have tended to make reference to a group's shared ethnicity, language, religion, historical tradition, culture or territorial

\footnotetext{
${ }^{59}$ See, eg., Buchheit (1978: 87), who argues that "The history of United Nations practice lends substantial support to the thesis that the principle of self-determination...is primarily a vehicle for decolonization, not an authorization of secession."

60 GA Res. 2625 (1970).

61 See, eg., Quebec decision, paras. 111-139. The content of the 'saving clause' was also reiterated by the Vienna Declaration of 1993. See World Conference on Human Rights, Vienna Declaration and Programme of Action, UN Doc. A/CONF.157/23, para. 2.

${ }^{62}$ For a critique of the doctrine of remedial secession, see Del Mar (2013: 79). See also Hilpold (2009: 55).

${ }^{63}$ Weller (2008: 59).
} 
connection. ${ }^{64}$ A UNESCO definition set out seven shared characteristics of a people, including a common historical tradition, racial or ethnic identity, cultural homogeneity, linguistic unity, and religious or ideological affinity. ${ }^{65}$ Similar criteria were outlined by the International Commission of Jurists in the context of Bangladesh's secession from Pakistan. ${ }^{66}$ It is further suggested that to qualify as a "people" a group should satisfy both objective and subjective elements: that it objectively shares a number of the characteristics mentioned above, and that it subjectively considers itself to be a people. ${ }^{67}$

Categorizing the population of Crimea as a "people" in accordance with such criteria is problematic. While Ethnic Russians comprise a clear majority of the territory's population according to the most recent census (58\%), Ukrainians and Tatars comprise sizeable proportions also (24 and $12 \%$ respectively), ${ }^{68}$ and it is difficult to speak of any single homogenous group of people which overwhelmingly represents the identity of Crimea. It could be said that more than one "people" inhabit Crimea. There are significant divisions in terms of national identity and language. Any purported assertion of a right to external self-determination is also being largely advanced by the Ethnic Russian population, which cannot alone represent the population of Crimea at large. ${ }^{69}$ This is in marked contrast to, say, the situation in Kosovo where Kosovar Albanians accounted for $90 \%$ of the province's population at the time of its declaration of independence from Serbia. That $96 \%$ of those voting in the March 16th referendum purportedly backed secession from the Ukraine is of little consequence given doubts over the reliability of the poll, disputes over the actual turnout and that those groups opposed to secession seem to have boycotted the referendum in large numbers. ${ }^{70}$ Similar difficulties apply to attempts to categorise the populations of Abkhazia and South Ossetia as "peoples" for the purposes of assessing their earlier attempts to secede from Georgia. Until relatively recently, ethnic Georgians were the largest single population group in Abkhazia, ${ }^{71}$ and while their numbers have declined considerably since the outbreak of conflict, ethnic Abkhazs only account for just over half of the territory's population,

\footnotetext{
64 See, eg., McCorquodale (1994: 866) and Knop (2002).

65 International Meeting of Experts on Further Study of the Concept of the Rights of Peoples, convened by UNESCO, Paris 27-30 November 1989, SHS 89/CONF.602/7, para. 23. The other characteristics listed were territorial connection and common economic life.

66 Secretariat of the International Commission of Jurists (1972: 70).

67 Sterio (2013: 16-18).

682001 Ukrainian Census.

69 The issue of determining the existence of a 'people' for self-determination purposes is even more problematic in the cases of Donetsk and Luhansk, where ethnic Russians account for a minority of the population as a whole, and the ethnic Ukrainian share of the population is considerably larger than in Crimea.

70 See, eg., 'Crimea's referendum was a sham display of democracy', The Guardian, 17 March 2014, www. theguardian.com/commentisfree/2014/mar/17/crimea-referendum-sham-display-democracy-ukraine.

71 According to 1989 census figures, available on the Government of Abkhazia website, http://abkhazia. gov.ge/index.php?lang_id=ENG\&sec_id=42.
} 
Georgians forming the second largest group, and Armenians the third. ${ }^{72}$ Although larger, the ethnic Ossetian population of South Ossetia only accounted for an estimated $67 \%$ of the territory's population at the time of its purported secession in 2008, ethnic Georgians still then representing a sizeable $25 \%$ of the overall population. $^{73}$

Notwithstanding serious doubts over whether there existed 'peoples' capable of exercising a right of secession in the cases of Crimea, South Ossetia and Abkhazia, it is unlikely that the circumstances necessary for any such right to have become exercisable had arisen. Any right to remedial secession generally arises only in extreme circumstances. A group exercising it must be able to point to severe instances of human rights abuses or acts of oppression directed against them by state authorities. ${ }^{74}$ Cassese argues that secession might be warranted where, "[T]he central authorities of a sovereign state persistently refuse to grant participatory rights to a religious or racial group, grossly and systematically trample upon their fundamental rights, and deny the possibility of reaching a peaceful settlement...there must be gross breaches of fundamental human rights." 75 Similarly, Weller suggests that a right of remedial secession will arise "where the central government persistently and systematically represses a territorially organised, and perhaps also constitutionally recognised, segment of the population..." or subjects that group to "persistent and discriminatory exclusion from governance." 76 In the Quebec case, the Canadian Supreme Court envisaged a possible right of secession in circumstances where a group is "subject to alien subjugation, domination or exploitation." 77 It is very difficult to establish the existence of such circumstances in respect of the treatment of Crimea's population by Ukrainian authorities, or Georgia's treatment of the South Ossetian and Abkhaz populations. ${ }^{78}$ Certainly any parallels with Kosovo are far-fetched.

Although there have been claims of violence directed against ethnic Russians within Ukraine and legitimate fears over the safety of Russian groups as a result of a surge in Ukrainian nationalism which underpinned the removal of the official status enjoyed by minority languages in Ukraine, ${ }^{79}$ it is difficult to place this on any comparable plane to those events which took place in Kosovo during the late 1990s. ${ }^{80}$ Notwithstanding President Putin's invocation of pressures placed upon

\footnotetext{
72 According to the 2011 Abkhazian census. See http://unpo.org/members/7854.

73 See, eg., Permanent Committee on Geographical Names for British Official Use, Georgia: a toponymic note concerning South Ossetia, www.pcgn.org.uk/Georgia\%20-\%20South\%20Ossetia-Jan07.pdf.

74 See, eg., Cassese (1995: 119-120), Ryngaert and Griffisen (2009: 575-576) and Jaber (2011: 934-940).

75 Cassese (1995: 119-120). See also Knop (2002: 74).

76 Weller (2008: 59).

77 Quebec decision, paras. 113-114.

78 See, eg., NuBberger (2009: 355-358) and Sterio (2013: 149-152).

79 See Quigley (2014).

${ }^{80}$ On atrocities in Kosovo, see, eg., O'Neill (2002: 21-35) and Independent International Commission on Kosovo (2000: 33-83). For comparison of Crimea and Kosovo, see Malyarenko and Galbraith (2013).
} 
Russians and the "Kosovo precedent", 81 as one commentator has noted "comparison [of Kosovo] with Crimea is strained. Kiev's rule is not as brutal as Belgrade's." 82

Furthermore, the western response to events in Kosovo during 1999-when NATO conducted military strikes against Serbian targets-was concerned solely with the alleviation of humanitarian suffering. ${ }^{83}$ In sharp contrast, Russian intervention in the Ukraine furthered the objective of the acquisition of Crimea, undermining any apparently humanitarian objective. Russia's own treatment of sections of the Crimean population has also been heavily criticised on human rights grounds. $^{84}$

\section{Intervention Leading to Secession and Annexation}

Although any right of secession in international law arises only in narrowly circumscribed circumstances, at the same time there is no prohibition upon acts of secession as such. This much was confirmed by the ICJ in its advisory opinion upon the legality of Kosovo's declaration of independence. ${ }^{85}$ Where secession arises in opposition to the will of the parent state, the response of the international community is central to legitimising or condemning the resulting state of affairs. Secession, or irredentism, is all the more controversial where it takes place against a backdrop of external intervention, as this serves to undermine what may otherwise be considered a lawful action. There is considerable support in international law for the principle that states are obliged to withhold recognition from territorial changes which are brought about by breaches of international legal norms, the so-called doctrine of collective non-recognition. ${ }^{86}$ This point was arguably made clear in the ICJ's advisory opinion in the Kosovo case, where in relation to declarations of independence it noted that, "Illegality attached to [some other] declarations of independence...stemmed not from the unilateral character of these declarations as such, but from the fact that they were, or would have been, connected with the unlawful use of force or other egregious violations of norms of general international law, in particular those of peremptory character (jus cogens)." 87

This view is reinforced by the international response to Northern Cyprus' purported secession from Cyprus in a case bearing some striking similarities to that of Crimea. Following intervention by Turkey, the Turkish Cypriot population in the

\footnotetext{
81 Speech of 18 March 2014.

82 Chesterman (2014: 2). See also Smith and Harari (2014: 26) and Malyarenko and Galbraith (2013: 918).

83 Although, for speculation as to ulterior motives on the part of intervening states, see Pinter (2000) and Ali (2000). Significantly, Kosovo's purported secession from Serbia came several years later and took the form of a proclamation of independent statehood.

${ }^{84}$ See Human Rights Watch (2014).

85 Accordance with international law of the unilateral declaration of independence in respect of Kosovo, ICJ Rep 2010, 141.

86 See Orakhelashvili (2008: 25-31), Vidmar (2009: 827-849) and Caspersen (2012: 28-30).

87 Kosovo opinion, para. 81. See also Article 41, ILC Articles on State Responsibility 2001.
} 
north of the island were able to separate from the Greek dominated south, ${ }^{88}$ in a manner akin to Crimea's secession from Ukraine following Russian intervention. Significantly, however, the Turkish Republic of Northern Cyprus has not been afforded recognition by any state other than Turkey. ${ }^{89}$ The UN Security Council declared Northern Cyprus' declaration of independence to be legally invalid and called upon states to withhold recognition. ${ }^{90}$ Northern Cyprus' purported secession was also implicitly condemned by the UN General Assembly. ${ }^{91}$ Where territory is regarded as having been annexed by an intervening state, the international community has consistently condemned such developments. ${ }^{92}$ The only obvious example of a situation in which recognition was extended to a change to the territorial status quo aided by external intervention is that of Bangladesh, where the secession of East Pakistan to form a new state was facilitated in large part by India's military intervention. ${ }^{93}$ However, this is hardly a comparable situation to that of Crimea or Georgia's secessionist entities, the catalogue of atrocities perpetrated against the population of East Pakistan by the authorities of its parent state being well documented. ${ }^{94}$

While the result of the Crimean referendum on the option of union with Russia may well represent a reliable and authoritative expression of the wishes of a majority of that territory's population, especially given that a majority of the population were ethnic Russians, it took place against the will of the parent state, Ukraine. What is more, it was arguably only possible as a result of the role played by Russia, an external actor. As Ukraine itself noted, "The declaration of independence by the Crimean Republic is a direct consequence of the application of the use of force and threats against Ukraine by the Russian Federation." 95 Without this it is inconceivable that any referendum or resulting territorial realignment of the territory would have been possible. As Allison notes, "The core issue is that Russia created an illegal territorial situation by using the threat of force," the referendum having taken place "in the intimidating presence of Russian troops." 96 Russia's role in Crimea's affairs mirrors to some extent its earlier involvement in South Ossetia and Abkhazia, both of which enjoy de facto 'independence' from Georgia in no small part due to the role played by Russia in their affairs. Both secessionist campaigns were aided by Russian military intervention, which was particularly decisive in the 2008 conflict. ${ }^{97}$ If Crimea's incorporation within Russia is the result

\footnotetext{
${ }^{88}$ On the case for remedial secession on the part of Turkish Cypriots, see Tocci (2003: 79-84) and Raic (2012: 124-127).

89 See Ronen (1979: 61-70).

90 SC Res 541 (1983).

91 GA Res 253 (XXXVII) (1983).

92 For example, Iraq's annexation of Kuwait was condemned by the Security Council (SC Res 662 (1990)), as was Israel's annexation of East Jerusalem (SC Res 267 (1969)).

93 See Buchheit (1978: 198-214) and Castellino (2000: 147-172).

94 See Secretariat of the International Commission of Jurists report (1972).

95 UN Doc. S/PV.7144, 6.

96 Allison (2014: 1266).

97 See NuBberger (2013: paras. 26-30).
} 
of actions that constitute violations of international law, the international community's sweeping denunciation and rejection of it is appropriate. ${ }^{98}$

The territorial integrity of sovereign states within Europe is guaranteed by the Helsinki Final Act. ${ }^{99}$ More significantly, Article 2 (4) of the UN Charter protects the territorial integrity and political independence of states against the use of force applied by other states. In respect of Crimea, serious issues of international law arise concerning Russia's intervention within Ukraine insofar as this may constitute a violation of Article 2 (4), as well as other norms which safeguard states' territory against external intervention. ${ }^{100}$ Russia was also obliged to respect Ukraine's existing borders under the terms of bilateral agreements between the two states. ${ }^{101}$

Where the armed forces of one state cross the borders of another state, there is a clear prima facie instance of unlawful intervention involving the use of force contrary to Article 2 (4). Initially Russia denied having despatched forces to Crimea prior to its referendum on union with Russia, but later admitted that Russian forces had entered the province. ${ }^{102}$ Although the extent to which Russia used force against the territorial integrity or political independence of the Ukraine may be debated, that it intervened in Crimea and was responsible for the application of coercive measures is largely undisputed. ${ }^{103}$ In any event it might also be noted that violations of Article 2 (4) can take more subtle forms. In the Nicaragua case, the International Court of Justice noted that a state could be held responsible for the armed activities of third party actors where these perform acts under its "effective control". ${ }^{104}$ In making this point, the ICJ relied on the UN General Assembly's earlier Definition of Aggression, ${ }^{105}$ which acknowledged that acts of aggression by states could include their sending of irregular forces. ${ }^{106}$ The onus is therefore on Russia to provide legal justification for intervention which negates a prima facie violation of Article 2 (4) of the UN Charter. Three principal possible justifications seem to have been hinted at in official Russian rhetoric: counter-coup, invitation, and humanitarian intervention/ protection of nationals. These echoed Russian claims advanced at the time of its

\footnotetext{
98 A view heavily supported by many states. For discussion, see Corten (2015: 35-38).

99 See Conference on Security and Co-operation in Europe Final Act 1975, Pt.I (a) (iv). See also Pt.I (a) (i)-(iii) on sovereign equality, refraining from the threat or use of force, and inviolability of frontiers. 100 For example, the doctrine of non-intervention. See GA Res. 2131 (XX); GA Res. 2625 (XXV).

101 See Budapest Memorandum, 5 December 1994, paras. 1-2; Treaty on Friendship, Cooperation, and Partnership 1997, Article 3. See further Marxsen (2014).

102 See 'Putin's remarks raise fears of future moves against Ukraine', The Washington Post, 17 April 2014, www.washingtonpost.com/world/putin-changes-course-admits-russian-troops-were-in-crimeabefore-vote/2014/04/17/b3300a54-c617-11e3-bf7a-be01a9b69cf1_story.html.

103 See UN Doc. S/PV. 7124, 1 March 2014, 2-3 (comments of Deputy UN Secretary-General and Ukrainian representative).

104 Military and Paramilitary Activities in and against Nicaragua (Nicaragua v United States of America) (Merits), ICJ Rep, 1986, para. 115.

105 Nicaragua case, para. 195. UN GA Res. 3314 (XXIX).

106 See Wilson (2012: 183). See also Gray (2004: 108-120).
} 
earlier interventions in support of the secessionist regions within Georgia, ${ }^{107}$ although from some perspectives they "stretched legal credibility even further." 108

The Ukrainian Parliament's impeachment and removal of President Yanyukovych was attacked by Russia as a western backed, illegal coup. ${ }^{109}$ Although the fact that nearly three quarters of Ukrainian MPs voted to impeach him would appear to have afforded some democratic legitimacy for the change of government in Kiev, strictly speaking the terms of the Ukrainian constitution set a higher standard which must be satisfied for impeachment to proceed. ${ }^{110}$ However, this is internationally irrelevant. Irrespective of the merits of this course of action, this is a domestic and not an international matter. It does not provide any legal authority for external intervention. However, its relevance must be seen in the context of the two principal justifications alluded to by Russia.

Russia claimed to have received an invitation from the ousted President Yanyukovch to intervene. ${ }^{111}$ State authorities may invite foreign forces onto their territories to assist in responding to crisis or conflict situations, ${ }^{112}$ but who exactly is entitled to issue this invitation depends upon which of two approaches are adopted in respect of the identification of the state's government: the 'effective control' and 'popular sovereignty' models. The former attaches significance to a government's exercise of effective control within the state, whereas the latter looks to its democratic legitimacy. ${ }^{113}$ International law appears to have provided no consistent practice upon the approach to be taken, ${ }^{114}$ although there is some evidence that the latter has gained in support in recent years. ${ }^{115}$ Nonetheless, neither is particularly helpful to Russia's argument. Yanyukovych had lost effective control within the Ukraine. Applying the 'effective control' theory of authority, this meant he had no power to issue such an invitation. While the alternative 'popular sovereignty' theory holds that a deposed leader or regime endowed with democratic legitimacy may still

\footnotetext{
107 Russia's justifications for action taken in respect of South Ossetia and Abkhazia broadly revolved around self-defence, fulfilment of peacekeeping functions, and the protection of civilians. See NuBberger (2013: para. 29), Petro (2008: 1528-1537) and Toomey (2009: 464-465). A controversial aspect of Russia's purported justifications was to claim protection of Russian nationals in South Ossetia and Abkhazia, these being essentially Georgian nationals it had dubiously conferred Russian citizenship upon in order to be able to claim an interest in their treatment. See further Petro (2008: 1534), Higgins and O'Reilly (2009: 582), Toomey (2009: 475-476) and Chatham (2011: 93-95).

108 Allison (2014: 1260).

109 See Speech by President Putin of 18 March 2014. See also UN Doc. S/PV.7134, at 15.

110 Article 111 sets out a series of procedures to be followed for a president to be removed following impeachment, which do not appear to have been followed. Furthermore, the decision to remove Yanyukovych did not quite receive the three quarters majority specified by Article 111 .

111 See, eg., UN Doc. S/PV. 7124, above n91, 5. See further Allison (2014: 1264-5).

112 Note, for example, the UN Security Council's welcoming of the French intervention in Mali at the request of its government: SC Res. 2100 (2013). See also the judgment of the ICJ in Armed Activities on the Territory of the Congo (DRC v Uganda), ICJ Rep, 2005, 168.

113 See Roth (1999: 136-149).

114 See Gray (2004: 83-87).

115 See, eg., Marxsen (2014: 374-380), for consideration of possible cases in which invitations emanating from democratically elected governments lacking effective control have resulted in intervention.
} 
be treated as the legitimate authority within the state, the scale of support for Yanyukovych's impeachment would suggest that the legitimacy conferred by popular sovereignty now resided with the new regime in Kiev.

Although not explicitly invoking the controversial doctrine of humanitarian intervention, Russia nonetheless referred to the need to protect Russian citizens within the Ukraine, ${ }^{116}$ an argument advanced at the time of its equally controversial incursion into the Georgian province of South Ossetia during 2008. ${ }^{117}$ While the existence of a right of humanitarian intervention is doubtful in itself, ${ }^{118}$ even those who advocate the existence of such a right set the threshold at which circumstances will entitle its exercise at a much greater level of severity than that seen in the treatment of the Russian population of Crimea. ${ }^{119}$ The legality of intervention for the narrower objective of protecting nationals is also disputed. ${ }^{120}$ Furthermore, Russia's policy of conferring nationality on large numbers of inhabitants of Crimea cast into doubt the validity of its claims in this regard. This approach was reminiscent of its actions in the earlier South Ossetian incident, where "the widespread distribution of Russian passports, especially to Ossetian residents, meant that Russia was able to 'manufacture' a population of nationals in Georgia that it claimed to be defending." 121 The better view within international law is that nationality claimed must be 'real and effective'. ${ }^{122}$ In any event, there was little evidence to suggest that this group faced any serious level of suffering at the hands of the Ukrainian authorities. ${ }^{123}$

\section{The Broader Legal and Political Context of Crimea}

In legal terms, any assessment of events in Crimea-and indeed earlier episodes involving secessionist pressures within the former Soviet space-is relatively straightforward. There is no general right to secede within international law and although secession is not prohibited either, the prevailing weight of international legal opinion holds it to be invalid when (1) it occurs in the face of the opposition of the parent state in the absence of exceptional circumstances which might warrant a right of 'remedial' secession in accordance with the principles contained within the

\footnotetext{
116 See, eg., Putin speech of 18 March.

117 See Petro (2008: 1525-1533) and Musselman (2010: 329-336).

118 The literature which the topic has generated is voluminous. See, eg., Chesterman (2001), Wheeler (2002) and Teson (2005).

119 See, eg., Cassese (1999: 27) who advocates that the requirements for humanitarian intervention should include "gross and egregious breaches of human rights involving loss of life of hundreds or thousands of innocent people, and amounting to crimes against humanity...", action to halt such atrocities being taken by a group of states, with support or non-opposition of a majority of UN member states, and the use of armed force being limited to halting the atrocities. None of these criteria were present in respect of any Russian intervention in Crimea.

120 See, eg., Franck (2002: 76-96) and Gray (2004: 126-129).

121 Green (2014: 3).

122 Green (2014: 3). See Nottebohm (Liechtenstein v Guatemala), ICJ Rep 1955, 4.

123 See Allison (2014: 1262) and Marxsen (2014: 373-374).
} 
'saving clause' of the Friendly Relations declaration; and (2) it is effected by external intervention. The Crimean episode exhibits both characteristics and the international community has overwhelmingly declined to extend recognition to Crimea's purported union with Russia.

International law does not, however, operate in a vacuum. Its development is informed by the actions of states, which in turn are driven by political agendas that do not always conform with the dominant body of thought upon the correct application of the core principles of international law. Regardless of the legal relationship between statehood and recognition, ${ }^{124}$ on a practical level issues pertaining to legal sovereignty over territory cannot be divorced from the political effects of recognition. Russia's intervention within Crimea may have produced a de facto situation that is irreversible, but as with other recent assertions of Russian authority in Abkhazia and South Ossetia, the international community appears unlikely to grant it the legitimating stamp of recognition. That secession and/or union with another state may be successfully effected de facto does not of itself have any legal bearing. This is apparent from the cases of East Timor, ${ }^{125}$ Western Sahara, ${ }^{126}$ and Northern Cyprus, ${ }^{127}$ all of which were, or have, been occupied for considerable periods of time with no resulting acceptance of any change to their territorial status on the part of the international community. Indeed, as Almqvist has noted, "from a practical standpoint, recognition is an essential condition for a new state actually to exercise in an effective manner the international rights and obligations that are incumbent on statehood and entering into relations with other states and thus become a fully-fledged member of the international community." 128 Of course, international political responses to the Crimean episode are complicated by the fact that Crimea does not purport to exist as an independent state-in contrast to, for example, Northern Cyprus - but rather as part of another state, Russia, which must become the target of efforts designed to cause international isolation. Sanctions have been imposed upon Russia in consequence of its intervention in Ukraine, ${ }^{129}$ but the longer term effects of these remain to be seen and it must be borne in mind that Russia is a major international power.

An important point which has been highlighted well by the Crimean episode is the inconsistency with which some states will seek to invoke norms of international law in support of their causes or to oppose the causes of others. It is a plausible claim that every instance of attempted secession comes with its own unique

\footnotetext{
124 The more popular declaratory theory of recognition considers the effects of recognition to be merely declaratory: they evidence a pre-existing fact, namely that X satisfies the criteria of statehood, or is part of state Y. The constitutive theory deems a territory's international status to be dependent upon the recognition of others. For discussion of both theories, see, eg., Shaw (2008: 445-454).

125 See, eg., Ronen (1979: 54-61) and Sterio (2013: 103-113).

126 See Castellino (2000: 173-258). See, also, Cassese(1995: 214-218) and Knop (2002: 110-167).

127 See Tocci (2003).

128 Almqvist (2013: 165, 170). See also Dugard and Raic (2006: 98), who note that "It is...difficult to maintain that an entity that has received recognition by none or very few states...can claim to be a State, as it cannot demonstrate its capacity to enter into relations with other States."

129 See, eg., 'How far do EU-US sanctions on Russia go?', BBC News Online, 15 September 2014, www.bbc.co.uk/news/world-europe-28400218.
} 
characteristics. Crimea is only the latest in a line of secessionist pressures which continue to challenge fundamental international legal norms. The task of international law is to ensure that these norms are clear, consistently applied, and capable of responding to the diverse range of situations which arise to threaten existing state boundaries. However, states remain the principal actors within international law, and adherence on their part to a consistent interpretation of its norms does not necessarily serve to complement their geopolitical objectives. It is striking that Russia deployed arguments in support of its involvement in Crimea's affairs which appear to have rested in part upon the existence of a right of selfdetermination for the population of Crimea, ${ }^{130}$ as well some kind of right of humanitarian intervention (or protection of nationals) underpinning the legitimacy of its intervention. Previously, Russia had displayed grave reluctance to acknowledge the existence of a right of secession for disadvantaged groups, ${ }^{131}$ and had been critical of justifications for military intervention claimed on humanitarian grounds. ${ }^{132}$ It is even more remarkable that Russia claimed support for its actions in the 'Kosovo precedent', ${ }^{133}$ given its condemnation of both the NATO led military intervention against the FRY in response to atrocities committed against the Kosovar Albanian population, ${ }^{134}$ as well as its outright rejection of any ground for Kosovo's later secession from Serbia. ${ }^{135}$ Significantly, however, Russia had attempted to invoke notions of remedial secession in support of South Ossetian and Abkhazian independence from Georgia, ${ }^{136}$ where such arguments potentially furthered its cause.

Although detailed assessments of the geopolitical dimensions to the Crimean episode are probably better left to scholars of international relations, an understanding of these is helpful in order to appreciate the factors which have driven the shift in legal rhetoric employed by Russia in attempts to legitimise its role in developments within Crimea. Politically, the Crimean issue forms merely part of a much larger regional power struggle. There is certainly a wider issue concerning relations between Russia and Ukraine more generally, conflict between Ukrainian authorities and Russian backed separatist groups having spread to other areas in the south-east of Ukraine, principally Donetsk and Luhansk, which have proclaimed their secession from the Ukraine and within which conflict continues to rage. However, Russia's interest in developments within Ukraine represents just one

\footnotetext{
130 See, eg., UN Doc. S/PV.7144, 8; UN Doc. A/68/PV. 80, 3.

131 See, eg., Memorandum on the maintenance of peace and stability in the CIS 1995, s.7, whereby the parties_-including Russia and Ukraine-agree "not to support separatist movements and separatist regimes in [their territories]...if they arise."

132 For example, Russia was one of the sponsors of a draft Security Council resolution which condemned NATO's intervention against the FRY in response to the atrocities perpetrated in Kosovo. See UN Doc. S/1999/328.

133 See Marxsen (2014: 384-388).

134 UN Doc. S/1999/328.

135 See Statement by Russia's Ministry of Foreign Affairs on Kosovo, of 17 February 2008, http:// archive.mid.ru//bdomp/brp_4.nsf/e78a48070f128a7b43256999005bcbb3/041c5af46913d38ac32573f30 027b380! OpenDocument.

136 UN Doc. S/PV.5969, 6-9.
} 
aspect of its more general concern for the future development of its relations with its neighbours within the former Soviet space. As noted by Allison, "Russian intervention in Ukraine is rooted in the dynamics of security relations and relative power." ${ }^{137}$ However, it "raises acute and more immediate uncertainties about future Russian policy towards neighbouring states and the stability of interstate relations in Eastern Europe..." ${ }^{138}$ In the perspectives of several commentators, there has been a resumption of "great power rivalry" between Russia and the West, which is reminiscent in some respects of the Cold War. ${ }^{139}$ The main source of tension concerns their respective degrees of influence within Russia's near abroad. Having already seen other former Soviet states drift towards integration within the EUEstonia, ${ }^{140}$ Latvia and Lithuania-as well as several former communist Eastern European states, Russia's foreign policy objectives include seeking to influence the external relations of its neighbours ${ }^{141}$ in a manner akin to the operation of the Monroe doctrine by the US. ${ }^{142}$ Ukraine's apparent movement towards possible absorption within EU and NATO structures was clearly a source of concern for Russia. ${ }^{143}$ However, Ukraine is just one example within recent years of the playing out of tensions between Russia and the West, and developments in Georgia and Moldova in particular have also received Russia's attention. ${ }^{144}$ In breakaway regions within these states, "the Russian government has supported separatism...the key element of Putin's strategy is to use these breakaway regions as perches from which to threaten the larger states that once governed them..Russian military forces operate in these regions and guarantee their security." 145 A deterioration in relations between Russia and pro-Russian regimes and western powers has already taken place and this latest episode threatens to harden these fault lines and potentially return the state of geopolitical affairs to one dominated by a new Cold War.

\section{Conclusions}

Prima facie, it is possible to draw some relatively simple conclusions from the Crimean episode. The prevailing weight of international legal opinion holds that Crimea's incorporation within Russia is unlawful. Although secession is not expressly prohibited under international law, nor is there a general right of secession and each instance must be judged with reference to its particular circumstances. It is certainly a tall claim to suggest that the Crimean population has suffered some

\footnotetext{
137 Allison (2014: 1269).

138 Allison (2014: 1256).

139 See, eg., Trenin (2014), March (2011), Malyarenko and Galbraith (2013: 920-926).

140 Estonia has an ethnic Russian population of $25 \%$ according to the 2011 census, data available at www.stat.ee.

141 See Smith and Hariri (2014: 37-38).

142 For a definition and overview of the Monroe doctrine, see Grant (2013).

143 See further Allison (2014: 1269-1275).

144 See Trenin (2014: 15-18). See also Allison (2014: 1275-1277).

145 Cullen Dunn and Bobick (2014: 406).
} 
sufficiently severe oppressive treatment of the kind which would justify the exercise of a right of 'remedial secession'. More important, however, is the widespread acceptance of the rule against recognition of territorial changes brought about by an unlawful act such as the use of force, as Russia's intervention within the territory of the Ukraine was clearly understood to be. The clear international consensus upon the Crimean episode should be apparent from the widespread condemnation of Crimea's incorporation within Russia, evidenced by resolutions of the UN Security Council and General Assembly.

Beyond legal pronouncements upon its validity, the process through which sovereignty over Crimea has effectively been removed from one state and handed to another highlight two fundamental difficulties inherent in the operation of international law within a world beset by geopolitical forces. Firstly, states are driven to act out of political or strategic objectives which are not always compatible with relevant norms of international law. Secondly, as a consequence, international legal norms find themselves stretched, reinterpreted, and inconsistently applied as best suits a given state's objectives in the circumstances. This does not mean those norms lose their force, but it does become crucial that the international community unites in opposing dubious legal claims. On this occasion it would appear that it has done so.

Acknowledgments Gary Wilson is grateful to his colleagues Dr. Nirmala Pillay and Dr. Diana Sankey for reading and commenting upon earlier drafts of this paper.

Open Access This article is distributed under the terms of the Creative Commons Attribution 4.0 International License (http://creativecommons.org/licenses/by/4.0/), which permits unrestricted use, distribution, and reproduction in any medium, provided you give appropriate credit to the original author(s) and the source, provide a link to the Creative Commons license, and indicate if changes were made.

\section{References}

Ali, T. 2000. NATO's Balkan Crusade. In Masters of the universe? NATO's Balkan Crusade, ed. T. Ali, 345-359. London: Verso.

Allison, R. 2014. Russian 'deniable' intervention in Ukraine: How and why Russia broke the rules. International Affairs 90(6): 1255-1297.

Almqvist, J. 2013. The politics of recognition: The question about the final status of Kosovo. In Statehood and self-determination: Reconciling tradition and modernity in international law, ed. D. French, 165-186. Cambridge: CUP.

Buchheit, L.C. 1978. Secession: The legitimacy of self-determination. New Haven: Yale University Press.

Bugajski, J. 2000. Ethnic relations and regional problems in independent Ukraine. In Ukraine: The search for a national identity, ed. S.L. Wolchik, and V. Zviglyanich, 165-183. London: Rowman \& Littlefield.

Caspersen, N. 2012. Unrecognized states. London: Polity.

Cassese, A. 1995. Self-determination of peoples: A legal reappraisal. Cambridge: CUP.

Cassese, A. 1999. Ex iniuria ius oritur: Are we moving towards international legitimation of forcible humanitarian countermeasures in the world community? European Journal of International Law 10(1): 23-30.

Castellino, J. 2000. International law and self-determination. Leiden: Martinus Nijhoff.

Chase, P. 1996. Conflict in the Crimea: An examination of ethnic conflict under the contemporary model of sovereignty. Columbia Journal of Transnational Law 34: 219-254. 
Chatham, R.P. 2011. Defense of nationals abroad: The legitimacy of Russia's invasion of Georgia. Florida Journal of International Law 23: 75-102.

Chesterman, S. 2001. Just war or just peace? Humanitarian Intervention and International Law, 2001. Oxford: OUP.

Chesterman, S. 2014. Crimean war 2.0: Ukraine and international law. Straits Times 14 March: 2-5. http://papers.ssrn.com/sol3/papers.cfm?abstract_id=2408872.

Christakis, T. 2015. Self-determination, territorial integrity and fait accompli in the case of Crimea. ZaoRV/Heidelberg Journal of International Law 75(1): 75-100.

Corten, O. 2015. The Russian intervention in the Ukrainian crisis: Was jus contra bellum 'confirmed rather than weakened'? Journal on the Use of Force and International Law 2(1): 17-41.

Crawford, J. 2006. The creation of states in international law, 2nd ed. Oxford: OUP.

Crawford, J. 1998. State practice and international law in relation to secession. British Yearbook of International Law 69: 85-118.

Cullen Dunn, E., and M.S. Bobick. 2014. The empire strikes back: War without war and occupation without occupation in the Russian sphere of influence. American Ethnologist 41(3): 405-413.

Davies, N. 1997. Europe: A history. London: Pimlico.

Del Mar, K. 2013. The myth of remedial secession. In Statehood and self-determination: Reconciling tradition and modernity in international law, ed. D. French, 79-108. Cambridge: CUP.

Dugard, J., and D. Raic. 2006. The role of recognition in the law and practice of secession. In Secession: International law perspectives, ed. M.G. Kohen, 94-137. Cambridge: CUP.

Franck, T. 2002. Recourse to force: State action against threats and armed attacks. Cambridge: CUP.

Gaweda, B., and M. Siddi. 2012. No settlement without a proactive policy: The EU and the secessionist conflicts in the post-soviet space. Berlin: Institut fur Europaische Politik.

Grant, T.D. 2013. Monroe doctrine. Max planck encyclopaedia of public international law online.

Gray, C. 2004. International law and the use of force, 2nd ed. Oxford: OUP.

Green, J. 2014. The annexation of Crimea: Russia, passportisation and the protection of nationals revisited. Journal on the Use of Force and International Law 1(1): 3-10.

Halperin, M.H., and D.J. Scheffer. 1992. Self-determination in the new world order. Washington, DC: Carnegie Endowment for International Peace.

Higgins, N., and K. O'Reilly. 2009. The use of force: Wars of national liberation and the right to selfdetermination in the south ossetian conflict. International Criminal Law Review 9: 567-583.

Hilpold, P. 2009. The Kosovo case and international law: Looking for applicable theories. Chinese Journal of International Law 8(1): 47-61.

Human Rights Watch. 2014. Rights in retreat: Abuses in Crimea. New York: Human Rights Watch.

Independent International Commission on Kosovo. 2000. The Kosovo report. Oxford: OUP.

Jaber, T. 2011. A case for Kosovo? Self-determination and secession in the 21 st century. International Journal of Human Rights 15(6): 926-947.

Knop, K. 2002. Diversity and self-determination in international law. Cambridge: CUP.

Koeck, H.F., D. Horn, and F. Leidenmuehler. 2009. From protectorate to statehood: Self-determination versus territorial integrity in the case of Kosovo and the position of the European Union. Vienna: NWV.

Liber, G.O. 1998. Imagining Ukraine: Regional differences and the emergence of an integrated state identity. Nations and Nationalism 4(2): 187-206.

Magosi, P.R. 1996. A history of Ukraine. Seattle: University of Washington Press.

Malyarenko, T., and D.J. Galbraith. 2013. Crimea: Competing self-determination movements and the politics at the centre. Europe-Asia Studies 65(5): 912-928.

March, L. 2011. Is nationalism rising in Russian foreign policy? The case of Georgia. Demokratizatsiya: The Journal of Post-Soviet Democratization 19(3): 187-208.

Marxsen, C. 2014. The Crimea crisis: An international law perspective. ZaoV 74: 367-392.

McCorquodale, R. 1994. Self-determination: A human right approach. International \& Comparative Law Quarterly 43: 857-885.

Meadwell, Hudson. 1999. Secession, states and international society. Review of International Studies 25 : 371-387.

Musgrave, T.D. 1997. Self-determination and national minorities. Oxford: OUP.

Musselman, T.B. 2010. Skirmishing for information: The flaws of the international legal system as evidenced by the Russian-Georgian conflict of 2008. Transnational Law \& Contemporary Problems 19: 317-350. 
Nanda, V.P. 1980. Self-determination outside the colonial context: The birth of Bangladesh in retrospect. In Self-determination: national, regional and global dimensions, ed. Y. Alexander, and R.A. Friedlander, 193-220. Boulder: Westview.

Navari, C. 2014. Territoriality, self-determination and Crimea after Badinter. International Affairs 90(6): 1299-1318.

Nemyria, H. 1999. Regional identity an interests: The case of Eastern Ukraine. In Between Russia and the West: Foreign and security policy of independent Ukraine, ed. K. Kurt Spillmann, A. Wenger, and D. Muller, 303-323. Oxford: Peter Lang.

NuBberger, A. 2013. South Ossetia. Max Planck Encyclopaedia of Public International Law Online.

NuBberger, A. 2009. The war between Russia and Georgia-Consequences and unresolved questions. Gottingen Journal of International Law 2: 341-364.

O’Neill, W.G. 2002. Kosovo: An unfinished peace. Boulder: Lynne Rienner.

Orakhelashvili, A. 2008. Statehood, recognition and the United Nations system: A unilateral declaration of independence in Kosovo. Max Planck Yearbook of United Nations Law 12: 1-44.

Petro, N.N. 2008. The legal case for Russian intervention in Georgia. Fordham International Law Journal 32(5): 1524-1549.

Pinter, H. 2000. The NATO action in Serbia. In Masters of the universe? NATO's Balkan Crusade, ed. T. Ali, 327-336. London: Verso.

Quigley, J. 2014. Finding a way forward for Crimea. Cambridge Journal of International and Comparative Law Online. http://cjicl.org.uk/2014/03/05/john-quigley-finding-way-forward-crimea/.

Raic, D. 2012. Statehood and the law of self-determination. Leiden: Martinus Nijhoff.

Ronen, D. 1979. The quest for self-determination. New Haven: Yale University Press.

Roth, B. 1999. Governmental illegitimacy in international law. Oxford: Clarendon Press.

Ryngaert, C., and C. Griffisen. 2009. The relevance of the right to self-determination in the Kosovo matter. In partial response to the agora papers. Chinese Journal of International Law 8(3): 573-586.

Sasse, G. 2002. Conflict-prevention in a transition state: The Crimean issue in post-Soviet Ukraine. Nationalism \& Ethnic Politics 8(2): 1-26.

Sheeran, S.P. 2011. International law, peace agreements and self-determination: The case of the Sudan. International \& Comparative Law Quarterly 60: 423-458.

Shuster, S. 2014. Moscow's man. Time 24 March: 20-25.

Secretariat of the International Commission of Jurists. 1972. The events in East Pakistan. Geneva: International Commission of Jurists.

Smith, B., and D. Harari. 2014. Ukraine, Crimea and Russia. London: UK House of Commons Research Paper.

Sterio, M. 2013. The right to self-determination under international law. London: Routledge.

Summers, J. 2013. The internal and external aspects of self-determination reconsidered. In Statehood and self-determination: Reconciling tradition and modernity in international law, ed. D. French, 229-249. Cambridge: CUP.

Summers, J. 2011. Kosovo: A precedent? Leiden: Brill.

Summers, J. 2007. Peoples and international law. Leiden: Brill.

Teson, F. 2005. Humanitarian intervention: An inquiry into law and morality, 3rd ed. New York: Transnational Publishers.

Tocci, N. 2003. Self-determination in Cyprus: Future options within a European order. In Contextualising secession, ed. B. Coppieters, and R. Sakwa, 71-96. Oxford: OUP.

Toomey, M. 2009. The August 2008 battle of South Ossetia: Does Russia have a legal argument for intervention? Tempe International \& Comparative Law Journal 23: 443-477.

Trenin, D. 2014. The Ukrainian crisis and the resumption of great-power rivalry. Moscow: Carnegie Moscow Center.

Vidmar, J. 2011-2012. South Sudan and the international legal framework governing the emergence and delimitation of new states. Texas International Law Journal 47(3): 541-559.

Vidmar, J. 2009. International legal responses to Kosovo's declaration of independence. Vanderbilt Journal of International Law 42: 779-851.

Weller, M. 2009. Contested statehood: Kosovo's struggle for independence. Oxford: OUP.

Weller, M. 2008. Escaping the self-determination trap. Leiden: Martinus Nijhoff.

Wheeler, N. 2002. Saving strangers: Humanitarian intervention in international society. Oxford: OUP.

White, S., I. McAlister, and V. Feklyunina. 2010. Belarus, Ukraine and Russia: East or west? British Journal of Politics \& International Relations 12(3): 344-367. 
Wilson, G. 2012. The impact of 9/11 on the use of force in international law: Ten years on. In 9/11 ten years after: Perspectives and problems, ed. R.E. Utley, 179-195. Farnham: Ashgate.

Wydra, D. 2004. The Crimea Conundrum: The tug of war between Russia and Ukraine on the questions of autonomy and self-determination. International Journal on Minority and Group Rights 10: 111-130. 